\title{
STUDI DESKRIPTIF PERAN PEREMPUAN DALAM PERENCANAAN PEMBANGUNAN PARTISIPATIF DI KOTA MATARAM
}

\author{
Abdul Muttalib \\ Universitas Nahdlatul Ulama Nusa Tenggara Barat \\ Program Studi Ekonomi Islam
}

\begin{abstract}
Abstrak; Penelitian ini bertujuanUntuk menganalisis bentuk partisipasi perempuan dalam Musrenbang/ MPBM Tingkat Kota Mataram dan untuk menganalisis kendala-kendala yang mempengaruhi tingkat peranan perempuan dalam Musrenbang/ MPBM Tingkat Kota Mataram. Penelitian ini, penulis menggunakan pendekatan penelitian kualitatif dengan menekankan pada pembangunan naratif atau deskripsi tekstual atas fenomena yang akan diteliti. Pendekatan kualitatif adalah suatu proses penelitian dan pemahaman yang berdasarkan pada metodologi yang menyelidiki suatu fenomena sosial dan masalah manusia. Pada pendekatan ini, peneliti menekankan sifat realitas yang terbangun secara sosial serta hubungan erat antara peneliti dan subjek yang diteliti. Hasil penelitian menunjukan bahwa Musrenbang Kota Mataram diselenggarakan berdasarkan pada Peraturan Walikota Mataram Nomor 8 Tahun 2016 Tentang Perubahan Atas Peraturan DaerahNomor 27 Tahun 2001 Tentang MusyawarahPembangunan Bermitra Masyarakat, pelaksanaan Musrenbang yang dilaksanakan di Kota Mataram Tahun 2017 telah berjalan sesuai dengan Peraturan Walikota Mataram.kehadiran perempuan di Kota Mataram belum mencapai kuota minimal 30\% dari jumlah peserta,keterlibatan perempuan dalam komisi fisik dan prasarana (0\%), komisi umum (11,8\%), komisi ekonomi (11,8\%) dan komisi sosial budaya (21,1\%). Akses perempuan didalam Musrenbang Kota Mataram Tahun 2017 melalui sidang komisi paling banyak berada di komisi sosial budaya karena keahlian perempuan lebih dimanfaatkan dalam komisi sosial budaya dibandingkan dengan komisi yang lainnya. Minimnya tingkat keterlibatan perempuan dalam Musrenbang Kota Mataram tahun 2017 disebabkan oleh beberapa factor : Beban kerja domestik yang menimbulkan beban ganda bagi perempuan yang hendak beraktivitas public, Masyarakat yang telah menyakini bahwa perempuan identik dengan domestik maka menjadi wajar jika banyak perempuan yang enggan untuk mengikuti aktivitas di forum publik seperti Musrenbang,rendahnya pendidikan perempuan yang berakibat tidak siapnya perempuan memasuki wilayah-wilayah publik yang kompetitif dan maskulin,aktivitas publik seperti waktu rapat yang mempertimbangkan kebutuhan perempuan
\end{abstract}

\section{Kata Kunci : Peran Perempuan, Perencanaan Pembangunan Partisipatif}

Abstract; This study aims to analyze the participation of women in Musrenbang / MPBM Kota Mataram and to analyze the constraints that affect the level of women's role in Musrenbang / MPBM Kota Mataram. This study, the authors use a qualitative research approach with emphasis on the construction of narrative or textual description of the phenomenon to be studied. A qualitative approach is a process of research and understanding based on a methodology that investigates a social phenomenon and a human problem. In this approach, researchers emphasize the nature of socially constructed reality as well as the close relationship between the researcher and the subject under study. The result of the research shows that Musrenbang of Mataram City is organized based on Mayor Regulation of Mataram Number 8 Year 2016 About Amendment Of Local Regulation Number 27 Year 2001 About Deliberation Of Community Partnership Development, Musrenbang implementation in Mataram City Year 2017 has run in accordance with Mayor of Mataram Regulation. the presence of women in the city of Mataram has not reached the minimum quota of 30\% of the participants, the involvement of women in physical commissions and infrastructure (0\%), general commissions (11.8\%), economic commissions (11.8\%) and social and cultural commissions $(21,1 \%)$. Women's access in the Musrenbang of Mataram City 2017 through the commission meeting is mostly in the socio-cultural commission because women's expertise is more utilized in socio-cultural commissions than with other commissions. The low level of women's 
involvement in Musrenbang Kota Mataram in 2017 is caused by several factors: Domestic workload that creates a double burden for women who want to move public, people who have believed that women are identical with domestic so it becomes natural if many women are reluctant to follow the activities in public forums such as Musrenbang, the low level of women's education resulting in women's unpreparedness into competitive and masculine public areas, public activities such as meeting times that take into account the needs of women

Keywords: Women's Role, Participatory Development Planning

\section{Pendahuluan}

Sistem Perencanaan Pembangunan Nasional Indonesia ada dua pendekataan top down dan bottom up tujuannya untuk menjamin keseimbangan antara prioritas nasional dengan aspirasi prioritas lokal, walaupun pada kenyatannya sebagian besar daerah belum mengakomodasi aspirasi lokal dikarenakan sebagian besar proposal proyek yang diajukan berdasarkan aspirasi lokal telah tersingkir dalam rapat kordinasi yang menempatkan proposal yang diajukan oleh tingkat pemerintahan yang lebih tinggi tanpa memperhatikan proposal yang diajukan oleh tingkat pemerintahan yang lebih rendah. Dengan adanya system perencanaan yang bersifat sentralistik dari atas kebawah menyebabkan partisipasi masyarakat dalam perencanaan pembangunan belum sempurna ini disebabkan partisipasi masyarakat hanya sebatas pada keikutsertaan masyarakat pada tahap pelaksanaan program-program kegiatan pemerintah saja, namun diperlukan pada saat dimulainya suatu perencanaan bahkan dalam pengambilan keputusan

Dalam prakteknya banyak daerah menyusun berbagai standar dan mekanisme perencanaan yang inovatif, dengan tanpa menegasikan sistem dan mekanisme yang sudah ada. Bahkan proses perencanaan yang diterapkan sangat kreatif dan tematik, seperti penyelenggaraan Musyawarah Perencanaan Pembangunan (Musrenbang).Pelaksanaan Musyawarah Pembangunan Bermitra Masyarakat (MPBM) telah dilaksanakan Pemerintah Kota Mataram sejak tahun 2002, yang mengacu pada Peraturan Daerah Nomor 27 Tahun 2001 tentang Musyawarah Perencanaan Bermitra Masyarakat (MPBM) sebagai wahana atau forum bersama dalam melaksanakan musyawarah perencanaan pembangunan sebagaimana halnya Musrenbang
Musyawarah

Perencanaan Pembangunan (Musrenbang), menggambarkan bagaimana warga saling berdiskusi memecahkan masalah konflik dan juga problem yang ada di masyarakat, merupakan agenda tahunan, dimana warga bertemu mendiskusikan masalah yang mereka hadapi dan memutuskan prioritas pembangunan jangka pendek, setelah itu diusulkan kepada pemerintah di level yang lebih tinggi melalui Badan Perencanaan Pembangunan Daerah (Bappeda)

Awal mula munculnya Musrenbang sebagai upaya mengganti system sentralistik dan top down masyarakat di tingkat lokal dan pemerintah, yang mempunyai tanggungjawab yang sama dalam membangun wilayahnya. Dengan kata lain forum musrenbang merupakan proses sinkronisasi program Pemerintah Kota Mataram dengan masyarakat dalam pencapaian tujuan pembangunan Daerah. Seperti dikemukakan sebelumnya bahwa keterlibatan stakeholders dalam memberikan aspirasi dan kebutuhan merupakan faktor sangat menentukan dalam menentukan keluaran hasil Musrenbang.

Dalam Peraturan Walikota Mataram Nomor: 35/KPTS/2004 tentang Pedoman Pelaksanaan MPBM, bertujuan untuk memberikan informasi kepada semua stakeholder tentang materi/ bahan pelaksanaan MPBM dan hasil dari proses semua bentuk MPBM untuk kemudian ditindaklanjuti, merujuk Surat Edaran Bersama Menteri Negara Perencanaan Pembangunan Nasional atau Kepala BAPPENAS dan Menteri Dalam Negeri Nomor 0259/ M.PPN/ I/ 2005050/166/SJ perihal Petunjuk Teknis Penyelenggaraan Musrenbang Tahun 2005

Keterlibatan masyarakat luas dalam proses perencanaan pembangunan sangatlah penting, begitu juga dengan peranan/ partisipasi perempuan dalam Musyawarah 
Perencanaan Pembangunan (Musrenbang) melalui forum Musyawarah Pembangunan Bermitra Masyarakat (MPBM). Dimana Forum MPBM menjadi media penting untuk mensosialisasikan hasil-hasil Perencanaan MPBM.

Dalam Petunjuk Pelaksanaan (Juklak) dan Petunjuk Teknis (Juknis) disebutkan bahwa perempuan harus dipastikan ikut berpartisipasi dalam pelaksanaan Musrenbang. Bahkan, perwakilan perempuan harus dipastikan masuk ke dalam setiap pengiriman delegasi di tahapan Musrenbang yang lebih tinggi, dengan berpartisipasinya perempuan di setiap Musrenbang, perempuan dapat berpartisipasi untuk memasukkan agendaagenda kebutuhannya sehingga kebutuhan dan kepentingannya dapat terwakili. Pentingnya partisipasi perempuan tidak lagi dapat diabaikan karena partisipasi perempuan dalam proses demokrasi adalah bagian dari demokrasi itu sendiri. Oleh karena itu, semua anggota masyarakat dari berbagai kelompok, golongan baik itu laki-laki ataupun perempuan perlu diikutsertakan dalam proses pengambilan keputusan di segala tingkatan

Salah satu indikator integrasi perempuan dalam pembangunan adalah tingkat partisipasi angkatan kerja (TPAK) perempuan disemua bidang lapangan kerja sebagai politikus, PNS, karyawan, buruh perusahaan termasuk petani, partisipasi perempuan hingga tahun 1998 saja sudah mencapai 40,2 persen.Kondisi ini dapat dipahami, karena begitu besar andil perempuan dalam pembangunan nasional yang diprediksi akan terus meningkat dari tahun ke tahun.Dengan pendekatan Women In Development Approach (WID) yang diperkenalkan oleh United States Agency for International Development (USAID) bahwa perempuan merupakan sumber daya yang belum dimanfaatkan secara optimal untuk memberikan sumbangan ekonomi dalam pembangunan. Ini berarti bahwa perempuan dan pembangunan telah menjadi sorotan dunia internasional termasuk lembaga swadaya masyarakat (LSM) dalam kajian yang lebih komprehensif.

Menyadari pentingnya hak dan peran perempuan dalam mengkontribusikan ide dalam kehidupan sosial, terutama dalam aspek-aspek pembangunan, maka sudah sepatutnya perempuan diberi kesempatan dan diberdayakan dalam lingkup Musrenbang (Musyawarah Perencanaan Pembangunan)

Dalam tahap pelaksanaan MPBM tingkat Kota Mataram, masyarakat yang terlibat didalamnya khususnya kehadiran perempuan di dalam forum ini sudah cukup baik, itu artinya bahwa keterlibatan perempuan dalam forum ini sama pentingnya dengan unsur masyarakat lainnya. Pada pelaksanaan MPBM tingkat Kota Mataram dalam kurun waktu 3 (tiga) tahun, diawali dari tahun 2014 sampai dengan tahun 2016 partisipasi kaum perempuan mengalami kenaikan prosentase dalam kehadirannya

Dari penjelasan di atas, diperoleh suatu gambaran bahwa antusiasme masyarakat Kota Mataram untuk ikut berpartisipasi sudah sangat baik, yang mana dalam kurun waktu 3 (tiga) tahun terakhir mengalami peningkatan, khususnya partisipasi perempuan dalam proses perencanaan pembangunan di Kota Mataram telah mengalami peningkatan. Namun demikian, keterwakilan dalam bentuk kehadiran saja sebenarnya belum cukup menjamin aspirasi dari bawah tersampaikan atau menjadi bagian dari pengambilan keputusan di tahap selanjutnya, akan tetapi diharapkan peran aktif perempuan pada proses perencanaan, dalam pengambilan keputusan, pelaksanaan keputusan dan memperoleh hasil atau manfaat dari keseluruhan tindakan yang berkaitan dengan upaya pembangunan yang dilaksanakan

\section{Rumusan Masalah}

Berdasarkan uraian di atas, masalah yang akan dikaji dalam penelitian ini adalah:

1. Bagaimana bentuk partisipasi perempuan dalam Musrenbang/ MPBM Tingkat Kota Mataram?

2. Kendala-kendala apa saja yang mempengaruhi tingkat peranan perempuan dalam Musrenbang/ MPBM Tingkat Kota Mataram??

\section{Landasan Teori}

\section{Perencanaan Pembangunan}

Pada haketnya Perencanaan merupakan suatu rangkaian proses kegiatan menyiapkan keputusan mengenai apa yang diharapkan terjadi seperti peristiwa, keadaan, suasana dan sebagainya. Perencanaan bukanlah masalah kira-kira, manipulasi atau teoritis tanpa fakta 
atau data yang kongkrit melainkan persiapan perencanaan harus dinilai. Bangsa lain yang terkenal perencanaannya adalah bangsa Amerika Serikat. Perencanaan sangat menentukan keberhasilan dari suatu program sehingga bangsa Amerika dan bangsa Jepang akan berlama-lama dalam membahas perencanaan daripada aplikasinya.

Pembangunan Jangka Panjang boleh dikatakan telah berhasil meletakkan landasan yang kuat bagi pembangunan Jangka Panjang berikutnya. Adapun tujuan Pembangunan Jangka Panjang adalah mewujudkan bangsa yang maju dan mandiri, sejahtera lahir batin dalam rangka mewujudkan masyarakat adil makmur dalam negara kesatuan Republik Indonesia berdasarkan Pancasila dan UUD 1945. Rumusan yang luas tersebut dapat kita sebut tujuan normatif atau visi normatif dari pembangunan nasional. Dalam rangka pencapaian tujuan normatif Pembangunan Jangka Panjang tersebut di rumuskan pula sebagai sasaran umum ialah terciptanya kualitas manusia dan kualitas masyarakat Indonesia yang maju dan mandiri.

\section{Pengertian Perencanaan Pembangunan}

MenurutRiyadi dan Bratakusumah (2005:7)perencanaan pembangunan dapat diartikan sebagai : Suatu proses perumusan alternatif-alternatif atau keputusan-keputusan yang didasarkan pada data-data dan fakta-fakta yang akan digunakan sebagai bahan untuk melaksanakan suatu rangkaian kegiatan/aktivitas kemasyarakatan, baik yang bersifat fisik (material) maupun nonfisik (mental dan spiritual) dalam rangka mencapai tujuan yang lebih baik".

Conyers dan Hills dalam Munir (2002; 25-26) mendefinisikan perencanaan sebagai suatu proses yang berkesinambungan yang mencakup keputusan-keputusan atau pilihan berbagai alternatif penggunaan sumberdaya untuk mencapai tujuan tertentu pada masa yang akan datang. Berdasarkan definisi tersebut, berarti ada empat elemen dasar perencanaan yakni: (1) Merencanakan berarti memilih; (2) Perencanaan merupakan alat pengalokasian sumber daya; (3) perencanaan merupakan alat untuk mencapai tujuan; dan (4) perencanaan untuk masa depan.

Widodo (2006 ; 3), menyatakan bahwa perencanaan didefinisikan sebagai upaya yang dilakukan oleh sebuah institusi publik untuk membuat arah kebijakan pembangunan yang harus dilakukan di sebuah wilayah baik negara maupun daerah dengan berdasarkan keunggulan dan kelemahan yang dimiliki wilayah tersebut. Artinya dalam sebuah proses perencanaan, lembaga perencana wajib memperhatikan kondisi sosial, budaya, ekonomi, keamanan, kondisi fisik, pembiayaan, dan kualitas sumberdaya yang ada di wilayah tersebut.

Terdapat 3 (tiga) prinsip utama yakni: partisipasi, transparansi danakuntabilitas, ini merupakan perwujudan sistem demokrasi di Indonesia. Dari ketiga prinsip itu, prinsip partisipasi sering diabaikan, khususnya partisipasi dari kaum perempuan.Partisipasi perempuan menjadi hal yang penting, karena dapat menyampaikan aspirasinya.

\section{Perencanaan Pembangunan Daerah}

Perencanaan

pembangunan diselenggarakan setiap tahun, ini dapatdiartikan sebagai sebuah proses penyusunan rencana yang mempunyai rentang waktu satu tahun yang merupakan rencana operasional dari rencana jangka panjang dan menengah yang berisi langkah-langkah penetapan tujuan serta pemilihan kebijakan/program/ kegiatan untuk menjawab kebutuhan masyarakat setempat.

Dokumen kunci perencanaan pembangunan daerah adalah terdiri dari (1) RPJMD sebagai produk perencanaan 5 tahunan, (2) RKPD sebagai dokumen perencanaan tahunan daerah, (3) Renstra SKPD sebagai dokumen perencanaan 5 tahunan SKPD, dan (4) Renja SKPD sebagai dokumen perencanaan tahunan daerah di tingkat SKPD.

Berdasarkan aktor yang melakukan proses penyusunan perencanaan pembangunan, Innes dalam Syaifullah (2008; 33) membedakannya dalam beberapa model yaitu :

\section{Technical Bureaucratic Planning}

Perencanaan ini berbasis kepada penilaian birokrasi atas alternatif yang terbaik untuk mencapai tujuan dengan mengembangkan analisis komparatif serta proyeksi, untuk membuat suatu rekomendasi bagi pengambil keputusan berdasarkan 
informasi dan penilaian atas dampak politik dan perubahan yang dikehendaki.

\section{Political Influence Planning ,}

Dalam model ini, perencana adalah elit pimpinan daerah atau anggota legislatif yang terpilih. Perencanaan berbasis pada aspirasi/harapan dari masing-masing konstituennya.

\section{Social Movement Planning,}

Perencanaan disusun berdasarkan pergerakan masyarakat dimana di dalamnya terdapat individu atau kelompok yang secara struktur tidak mempunyai kekuatan, bergabung bersama dengan tujuan yang sama.

\section{Collaborative Planning,}

Dalam model ini setiap partisipan bergabung untuk mengembangkan misi dan tujuannya, menyampaikan kepentingannya untuk diketahui bersama, mengembangkan saling pengertian atas masalah dan perjanjian yang mereka butuhkan, dan kemudian bekerja melalui serangkaian tugas yang diperjanjikan bersama untuk mencapai kesejahteraan bersama

\section{Partisipasi Masyarakat}

Keterlibatan masyarakat di dalam penyusunan perencanaan pembangunan sangat ditekankan dalam Undang-Undang Nomor 25 Tahun 2004 tentang Sistem Perencanaan Pembangunan Nasional. Pendekatan partisipatif masyarakat terdapat pada 4 (empat) pasal Undang-Undang ini yaitu pada Pasal 2, Pasal 5, Pasal 6 dan Pasal 7. Sistem perencanaan yang diatur dalam UU 25/2004 dan aturan pelaksanaannya menerapkan kombinasi pendekatan antara top-down (atasbawah) dan bottom-up (bawah-atas), yang lebih menekankan cara-cara aspiratif dan partisipatif. Dengan adanya program-program partisipatif memberikan kesempatan secara langsung kepada masyarakat untuk berpartisipasi dalam rencana yang menyangkut kesejahteraan mereka dan secara langsung juga melaksanakan sendiri serta memetik hasil dari program tersebut. Selain uu no. 25 tahun 2004 terdapat peraturan perundang- undangan lain yang menekankan perlunya partisipasi masyarakat dalam perencanaan pembangunan yakni : Undang-Undang Nomor 32 Tahun 2004 Tentang Pemerintahan Daerah dan Peraturan Pemerintah Republik Indonesia Nomor 8 Tahun 2008 Tentang Tahapan, Tata
Cara Penyusunan, Pengendalian dan Evaluasi Pelaksanaan Rencana Pembangunan Daerah.

\section{Definisi Partisipasi Masyarakat}

Partisipasi diartikan sebagai keikutsertaan seseorang secara sukarela tanpa dipaksa sebagaimana yang dijelaskan Sastropoetro (1988) (dalam Lugiarti, 2004 : 7) bahwa partisipasi adalah keterlibatan secara spontan dengan kesadaran disertai tanggung jawab terhadap kepentingan kelompok untuk mencapai tujuan.

Menurut Mubyarto (1985) (dalam Lugiarti, 2004 : 8), partisipasi sebagai kesadaran untuk membantu berhasilnya setiap program sesuai dengan kemampuan setiap orang tanpa berarti mengorbankan kepentingan diri sendiri.Partisipasi sangat penting dalam pembangunan, karena pembangunan merupakan kegiatan yang berkesinambungan. Dalam pembangunan seperti itu sangat dibutuhkan pelibatan orang sebanyak mungkin. Sehingga tanpa partisipasi dari seluruh masyarakat pembangunan sukar dapat berjalan dengan baik.

Partisipasi merupakan masukan dalam proses pembangunan dan sekaligus menjadi keluaran atau sasaran dari pelaksanaan pembangunan. Partisipasi dalam konteks pembangunan desa mencakup keikutsertaan atau keterlibatan warga dalam proses pengambilan keputusan, dan dalam penerapan program yaitu adanya pembagian keuntungan atau manfaat dari hasil pelaksanaan kegiatan seta keterlibatan warga dalam mengevaluasi kegiatan tersebut. Konsep partisipasi dimaksud menggambarkan tahapan partisipasi dalam proses pembangunan, yang mencakup (1) partisipasi pada tahap perencanaan, (2) partisipasi pada tahap pelaksanaan, (3) partisipasi pada tahap pemanfaatan dan (4) partisipasi pada tahap penilaian hasil pembangunan

Peran serta masyarakat, memegang peranan penting dalam perencanaan pembangunan, karena masyarakat saat ini tidak boleh lagi dianggap sebagai obyek pembangunan tetapi harus ditempatkan sebagai subyek pembangunan bersama-sama dengan pemerintah. Artinya, masyarakat harus di dorong untuk aktif terlibat dalam proses pembangunan mulai dari perencanaan, pelaksanaan, pengawasandan evaluasi serta 
pemeliharaan dan pengembangan hasil pembangunan.

Selanjutnya Oetomo (2002 : 30) menyatakan bahwa secara garis besar peran serta masyarakat dalam perencanaan meliputi :

1. Pemberian masukan dalam penentuan arah pembangunan;

2. Mengidentifikasikan berbagai potensi dan masalah pembangunan;

3. Pemberian masukan dalam perumusan rencana tata ruang;

4. Pemberian informasi, saran dan pertimbangan atau pendapat dalam penyusunan strategi dan arah kebijakan pembangunan;

5. Pengajuan keberatan terhadap rancangan pembangunan;

6. Kerjasama dalam penelitian dan pengembangan;

7. Bantuan tenaga ahli.

6. Faktor-faktor yang Mempengaruhi Partisipasi

Partisipasi masyarakat dalam proses pembangunan akan terwujud sebagai suatu kegiatan nyata apabila terpenuhi adanya tiga faktor utama yang mendukungnya, yaitu (1) kemauan, (2) kemampuan, dan (3) kesempatan bagi masyarakat untuk berpartisipasi Slamet (1992) (dalam Sumardjo dan Saharudin, 2003 : 46).

\section{Partisipasi Perempuan dalam \\ Perencanaan Pembangunan}

Berbagai pendekatan telah dilakukan pemerintah mulai dari WID, WAD dan GAD. Women In development (WID) adalah pengintegrasian perempuan dalam pembangunan dengan menekankan pada upaya mendorong perempuan agar dapat memberikan sumbangan produktif terhadap pembangunan. Selanjutnya adalah pendekatan WAD, dalam pendekatan WAD tidak dibahas letak kedudukan laki-laki dan perempuan. Sudah ada pemahaman bahwa antara laki-laki dan perempuan memiliki kedudukan, kesempatan, dan peran yang sejajar. Terakhir adalah pendekatan Gender and Development (GAD), merupakan pendekatan yang berupaya untuk mengatasi kesenjangan gender dengan memberikan kesempatan yang setara bagi perempuan dan laki-laki untuk berpartisipasi penuh dalam pembangunan, serta memberikan akses kepada kontrol pembangunan. Berangkat dari pemahaman bahwa perempuan juga memiliki kesempatan untuk ikut berpartisipasi dalam pembangunan.

\section{Peran dan Partisipasi Perempuan dalam Pembangunan}

Di dalam pembangunan, perempuan juga merupakan subyek yang seharusnya dilibatkan juga dalam pembangunan baik itu dalam prosesnya maupun manfaatnya. Pemerintah juga berupaya meningkatkan peran perempuan dalam pembangunan melalui landasan yuridis Instruksi Presiden Nomor 9 Tahun 2000 tentang Pengarusutamaan Gender (PUG) dalam pembangunan nasional yang mengamanatkan agar setiap lembaga pemerintah memasukkan kesetaraan dan dan keadilan gender (KKG) dalam setiap tahapan kegiatan pembangunannya, baik di tahap perencanaan, pelaksanaan, maupun monitoring dan evaluasi. Tujuan dari PUG yang merupakan komitmen nasional maupun internasional ini adalah agar perempuan dan laki-laki mempunyai kesempatan dan berpartisipasi serta memiliki kontrol dan manfaat yang sama dalam pembangunan sehingga pada akhirnya dapat mengurangi ataupun mempersempit kesenjangan gender diberbagai bidang kehidupan.

Menurut Keputusan Menteri Dalam Negeri Nomor 132 Tahun 2003 tentang Pedoman Umum Pelaksanaan Pengarusutamaan Gender Dalam Pembangunan Di Daerah, kesetaraan dan keadilan gender adalah suatu kondisi yang adil dan setara dalam hubungan kerjasama antara perempuan dan laki-laki.

Kesetaraan dan keadilan gender menjadi hal yang sangat penting karena dapat menjadi upaya untuk menghilangkan diskriminasi antara perempuan dan laki-laki. Sehingga antara perempuan dengan laki-laki sama-sama mempunyai akses untuk dapat berperan secara maksimal baik sebagai pelaku maupun penikmat pembangunan.

Menurut UNESCO seperti yang dikutip oleh Ismi, Dwi Astuti (2008: 25), definisi kesetaraan gender dan keadilan gender adalah sebagai berikut:

"Kesetaraan antara laki-laki dan perempuan merupakan konsep yang menyatakan bahwa semua manusia (baik laki-laki maupun perempuan) bebas mengembangkan 
kemampuan personal mereka dan membuat pilihan-pilihan tanpa dibatasi oleh stereotype, peran gender yang kaku dan prasangka-prasangka. Hal ini bukan berarti bahwa perempuan dan laki-laki harus selalu sama tetapi hak dan tanggung jawab dan kesempatannya tidak dipengaruhi oleh apakah mereka dilahirkan sebagai laki-laki atau perempuan".

"Keadilan gender adalah keadilan dalam memperlakukan perempuan dan laki - laki sesuai kebutuhan mereka. Hal ini mencakup perlakuan yang setara atau perlakuan yang berbeda tetapi diperhitungkan ekuivalen dalam hak, kewajiban, kepentingan, dan kesempatannya".

Partisipasi dan peranan perempuan dalam pembangunan adalah keikutsertaan perempuan dalam proses perencanaan, pelaksanaan serta evaluasi. Peranan wanita dalam pembangunan yang berwawasan gender. Peranan wanita dalam pembangunan adalah hak dan kewajiban yang dijalankan oleh wanita pada status atau kedudukan tertentu dalam pembangunan, baik pembangunan di bidang politik, ekonomi, sosial budaya maupun pembangunan di bidang pertahanan dan keamanan, baik di dalam keluarga maupun di dalam masyarakat.

\section{Pengertian Musrenbang}

Musrenbang adalah forum perencanaan (program) yang dilaksanakan oleh lembaga publik yaitu pemerintah daerah, bekerja sama dengan warga dan para pemangku kepentingan lainnya.Musrenbang adalah hasil assesmen paling penting terhadap usulan program yang prioritas dari masyarakat karena apa yang dihasilkan merupakan kebutuhan masyarakat yang sebenarnya. Dijelaskan, mengacu pada aturan hukum yang berlaku, dalam hal ini UU No 25 Tahun 2004 tentang Strategi Perencanaan Pembangunan Nasional, maka partisipasi masyarakat harus menjadi prioritas utama dalam merencanakan pembangunan sebagai bentuk dari proses demokrasi.

Agar Musrenbang lebih bermakna serta kelanjutan pembangunan kita berharap kepada Satuan Kerja Perangkat Daerah (SKPD) mensinkronkan kegiatan yang ada di unit kerjanya dengan kebutuhan masyarakat, sehingga dana yang ada di SKPD pemanfataannya lebih maksimal untuk kepentingan masyarakat. Wildan menambahkan bila suatu perencanaan sudah disusun dengan rapi dan matang diyakini sistem penyelenggaraan pemerintahan akan berlangsung baik sesuai dengan harapan masyarakat serta visi dan misi pemerintah daerah.Musrenbang kita tahu adalah proses musyawarah masyarakat tentang pembangunan daerah yang di laksanakan guna untuk mendapatkan suatu kesepakatan di antara masyarakat di setiap daerah yang akan di adakan pembangunan.Musrenbang adalah forum di mana masyarakat dapat menyampaikan aspirasi meraka,dalam proses pembangunan yang akan di laksanakan tentang bagaiman yang seharusnya di lakukan pemerintah serta sebaliknya yang harus di lakukan masyarakat dalam pembnguna yang akan di laksanakan.musrenbang adalah proses memajukan setiap daerah mulai dari desa/kelurahan,kecamatan,kabupaten/kota ,provinsi hingga pusat.

Peran dan fungsi Musrenbang ialah untuk mencapai konsensus dan kesepakatan mengenai:

1. Prioritas program dan kegiatan SKPD untuk dibahas dalam Forum SKPD

2. Penentuan perwakilan dari kecamatan yang akan menghadiri Musrenbang kabupaten

\section{METODE PENELITIAN}

Dalam penelitian ini, penulis menggunakan pendekatanpenelitian kualitatif dengan menekankan pada pembangunan naratif atau deskripsi tekstual atas fenomena yang akan diteliti. Pendekatan kualitatif adalah suatu proses penelitian dan pemahaman yang berdasarkan pada metodologi yang menyelidiki suatu fenomena sosial dan masalah manusia.

Pada pendekatan ini, peneliti menekankan sifat realitas yang terbangun secara sosial serta hubungan erat antara peneliti dan subjek yang diteliti. Bogdan dan Taylor (Moleong, 2007:3) mengemukakan bahwa metodologi kualitatif merupakan prosedur penelitian yang menghasilkan data deskriptif berupa kata-kata tertulis maupun lisan dari orang-orang dan perilaku yang diamati. Data deskriptif adalah penelitian yang memberi gambaran secara cermat mengenai individu atau kelompok 
tertentu tentang keadaan dan gejala yang terjadi.

Dalam penelitian kualitatif, data studi kasus dapat diperoleh dari semua pihak yang bersangkutan, baik melalui wawancara, observasi, partisipasi, dan dokumentasi. Data yang diperoleh dari berbagai cara itu hakikatnya untuk saling melengkapi. Ada kalanya data yang diperoleh dari wawancara belum lengkap, sehingga harus dicari lewat cara lain, seperti observasi, dan partisipasi.

Penelitian dilakukan di Kantor Badan Perencana Pembangunan Daerah Kota Mataram NTB. Pemilihan lokasi ini dikarenakan kedekatan peneliti dengan obyek penelitian, dimana Kota Mataram adalah tempat peneliti berdomisili dan bekerja, sehingga memberikan kemudahan bagi peneliti dalam melakukan penelitian dan mengumpulkan data. Sedangkan waktu penelitian ini dilakukan sekitar bulan nopember 2017.

\section{Jenis dan Sumber Data}

Sumber data penelitian yaitu sumber subjek dari tempat mana data bisa didapatkan. Sumber data terbagi menjadi dua yaitu data primer dan data sekunder. Data primer adalah data yang diperoleh peneliti secara langsung dari sumbernya (informan), sementara data sekunder adalah data yang diperoleh peneliti dari sumber yang sudah ada.

\section{Informan}

Subjek penelitian disebut dengan informan, informan adalah orang-orang yang bisa memberikan informasi terkait dengan apa yang diangkat dalam penelitian tersebut. Teknik penentuan informan dengan cara melakukan observasi dan wawancra.

Burhan Bungin $(2011 ; 78)$ menyatakan, informan penelitian adalah "subyek yang memahami informasi dari obyek penelitian sebagai pelaku maupun orang lain yang memahami obyek penelitian". Obyek penelitian ini adalah realitas yang terjadi dalam organisasi pemerintahan daerah sebagai sebuah komunitas, yang didalamnya terjadi interaksi antara individu. Atas dasar itu informan yang dipilih dalam penelitian ini adalah para pihak yang terlibat langsung dan mempunyai pengalaman dalam proses perencanaan pembangunan daerah di Kota Mataram.

\section{Teknik Analisis Data}

Penelitian ini menggunakan metode kualitatif deskriptif berupa kata-kata atau lisan dari orang-orang atau institusi yang diamati. Pendekatan ini dilakukan dengan menggunakan metode deskriptif untuk dapat memperoleh gambaran mengenai realitas sosial yang kompleks mengenai partisipasi langsung perempuan.

Data yang diperoleh kemudian dianalisis dengan menggunakan analisis gender model Harvard dengan kategori profil aktivitas, akses, kontrol dan manfaat. Kerangka analisis Harvard meliputi empat komponen yaitu:

1. Profil Aktifitas, didasarkan pada konsep pembagian dengan data terpilah jenis kelamin. Profil aktifitas ini merinci kegiatan nyata menurut umur (siapa mengerjakan apa), penjadwalan (alokasi waktu) untuk kelompok-kelompok sosial ekonomi.

2. Profil Akses, siapa yang mempunyai akses terhadap sumberdaya produktif, perempuan memperoleh sumber daya apa, bagaimana perempuan dan laki-laki bisa memperoleh dan menikmati sumber daya tersebut.

3. Profil Kontrol dan Manfaat, merinci sumber-sumber apa yang dikuasai laki-laki dan perempuan untuk melaksanakan kegiatannya dan manfaat apa yang diperoleh setiap orang dari hasil kegiatan tersebut. Profil ini memperlihatkan siapa yang memiliki akses kepada sumberdaya dan kontrol atas penggunaannya.

Analisisfaktor-faktor yang Mempengaruhi Kegiatan, Akses dan Kontrol; Berpusat pada faktor-faktor dasar, yang menentukan pembagian kerja berdasarkan gender. Analisis disini dilakukan untuk mengidentifikasi faktorfaktor yang mempengaruhi perbedaan antara laki-laki dan perempuan. Karena pekerjaan yang dilakukan laki-laki dan perempuan berubah dari waktu ke waktu sebagai akibat dari proses pembangunan atau perubahan lingkungan.

\section{Keabsahan Data}

Demi terjaminnya keakuratan data, maka peneliti akan melakukan keabsahan data. Data yang salah akan menghasilkan penarikan kesimpulan yang salah, demikian pula 
sebaliknya, data yang sah akan menghasilkan kesimpulan hasil penelitian yang benar.

Kebenaran atau validitas harus dirasakan merupakan tuntutan yang terdiri dari tiga hal menurut Alwasilah (dalam Bachri, 2010:54) "yakni: 1) deskriptif, 2) interpretasi, dan 3) teori dalam penelitian kualitatif". Untuk menetapkan keabsahan data diperlukan teknik pemeriksaaan.

\section{HASIL ANALISIS DAN PEMBAHASAN}

1. Pelaksanaan MPBM di Kota Mataram

Dari hasil penelitian penulis dengan menggunakan data dokumentasi dan data observasi, pelaksanaan Musrenbang yang dilaksanakan di Kota Mataram Tahun 2017 telah berjalan sesuai dengan PeraturanWalikota Mataram Nomor Nomor 8 Tahun 2016 Tentang Perubahan Atas Peraturan DaerahNomor 27 Tahun 2001 Tentang MusyawarahPembangunan Bermitra Masyarakadengan melibatkan seluruh unsur di masyarakat Kota Mataram

Sesuai dengan tahapan-tahapan Musrenbang berdasarkan Peraturan Walikota Mataram Nomor Nomor 8 Tahun 2016 Tentang Perubahan Atas Peraturan DaerahNomor 27 Tahun 2001, persidangan dalam Musrenbang Kota Mataram 2017 meliputi tiga sidang, dengan masing-masing hasil sidang sebagai berikut:

a. Sidang Pleno I

Dalam sidang pleno I menghasilkan:

- Dipilihnya pimpinan sidang dipimpin oleh Steering Commiittee

- Disahkannya tata tertib;

- Pemaparan prioritas program atau kegiatan pembangunan di kecamatan dan hasil evaluasi pembangunan tahun sebelumnya oleh Camat atau pemerintah Kecamatan;

- Pemaparan prioritas program atau kegiatan kotan tahun berikutnya beserta informasi perkiraan Jumlah Alokasi Dana Bantuan Pembangunan kota (Block Grant);

- Pemaparan masalah utama yang dihadapi oleh masyarakat kecamatan;

- Penetapan tata cara penyeleksian prioritas kegiatan.

b. Sidang Komisi

Dalam sidang komisi menghasilkan:

- Penyusunan, validasi dan rekapitulasi prioritas kegiatan dalam rangka pemecahan masalah: a) yang akan didanai dengan Dana Bantuan Pembangunan Kecamatan (Block Grant) dan atau Swadaya Masyarakat;

b) yang akan diusulkan pada Musrenbangcam untuk ditangani SKPD.

c. Sidang Pleno II

Dalam sidang pleno II menghasilkan:

- Pemaparan hasil sidang komisi;

- Tanggapan;

- Pengesahan hasil sidang pleno II;

- Pembentukan Tim Penyempurnaan Perumusan;

- Penyerahan hasil Musrenbang kepada Panitia Pengarah untuk diteruskan kepada Penanggung Jawab;

- Pembentukan Tim Perencana Kegiatan Pembangunan, Tim Pelaksana Kegiatan Pembangunan dan Tim Monitoring dan Evaluasi Kegiatan Pembangunan yang prosesnya dipimpin oleh Penanggung Jawab;

- Penandatanganan Berita Acara hasil-hasil Musrenbang diwakili oleh Pimpinan Sidang Pleno dan Ketua Sidang Komisi

\section{Aktivitas Perempuan Dalam Musrenbang}

\section{Kota Mataram}

Dari profil aktivitas yang dilakukan oleh perempuan dalam forum Musrenbang Kota Mataram Kota Mataram tahun 2017 disimpulkan bahwa ternyata kehadiran perempuan di kelurahan Kota Mataram belum mencapai kuota minimal $30 \%$ dari jumlah peserta, seperti yang tertulis dalam Peraturan Walikota Mataram Nomor 8 Tahun 2016. Sekalipun jumlah prosentase perempuan hanya mencapai $11,6 \%$ dari jumlah keseluruhan peserta, dalam forum tersebut perempuan tidak hanya hadir melainkan juga aktif dengan memberikan banyak masukan di dalam forum.

\section{Akses Perempuan Dalam Musrenbang Kota Mataram}

Dari hasil observasi penulis, keterasingan perempuan dalam urusan-urusan yang berkaitan dengan sarana-prasarana pembangunan terlihat jelas oleh salah satu informan perempuan yang menjadi tim penyempurna rumusan Daftar Skala Prioritas. Dalam rapat kecil paska Musrenbang untuk menyempurnakan rumusan DSP, peneliti mengamati bahwa informan perempuan tersebut terlihat bingung dengan pembahasanpembahasan tentang fisik dan prasarana. Maka 
cukup beralasan apabila banyak perempuan yang menganggap bahwa komisi fisik dan prasarana bukan komisi yang tepat untuk perempuan.

Dari hasil penelitian yang dilakukan oleh peneliti melalui wawancara dan juga melalui pengamatan secara langsung, ditarik kesimpulan bahwa dari profil akses yang diperoleh perempuan dalam forum Musrenbang Kota Mataram tahun 2017 disimpulkan bahwa keterlibatan perempuan dalam komisi fisik dan prasarana $(0 \%)$, komisi umum (11,8\%), komisi ekonomi (11,8\%) dan komisi sosial budaya (21,1\%). Akses perempuan didalam Musrenbang Kota Mataram Tahun 2017 melalui sidang komisi paling banyak berada di komisi sosial budaya karena keahlian perempuan lebih dimanfaatkan dalam komisi sosial budaya dibandingkan dengan komisi yang lainnya.

\section{Kontrol Perempuan Dalam Musrenbang \\ Kota Mataram}

Dari hasil penelitian, diketahui bahwa kontrol perempuan didalam forum Musrenbang Kota Mataram tahun 2017 masih kurang karena dari sekian banyak kepengurusan panitia Musrenbang, sama sekali tidak ada posisi strategis sebagai ketua ataupun wakil ketua yang diduduki oleh perempuan. Keseluruhan perempuan lebih memilih untuk menjadi anggota saja. Faktor yang berpengaruh diantaranya adalah tidak percaya dirinya perempuan didalam forum publik karena selama ini perempuan lebih banyak berkutat di wilayah domestik. Faktor beban ganda (double burden) sehingga perempuan akan berupaya untuk menyelesaikan pekerjaan rumah tangganya terlebih dahulu sebelum menjalani aktivitas publik. Selain kedua faktor tersebut, juga dikarenakan faktor religi yang sudah mengakar sehingga masyarakat akan menilai sebagai hal yang tabu apabila terdapat perempuan yang kedudukannya di atas laki-laki.

\section{Manfaat Yang Diperoleh Perempuan Di \\ Dalam Musrenbang Kota Mataram}

Kesimpulan yang dapat ditarik adalah daftar skala prioritas pembangunan hasil Musrenbang Kota Mataram tahun 2017 yang responsif perempuan masih sedikit, namun demikian perempuan di Kota Mataram telah memperoleh manfaat yang besar dari
Musrenbang karena forum ini telah memperhatikan aspirasi, kepentingan dan kebutuhan perempuan

\section{Faktor-Faktor Yang Menghambat Perempuan Berpartisipasi Dalam Musrenbang Kota Mataram}

Minimnya tingkat keterlibatan perempuan dalam Musrenbang Kota Mataram tahun 2017 disebabkan oleh beberapa faktor :

1. Beban kerja domestik (pekerjaan rumah tangga) yang menimbulkan beban ganda bagi perempuan yang hendak beraktivitas publik

2. Masyarakat yang telah menyakini bahwa perempuan identik dengan domestik maka menjadi wajar jika banyak perempuan yang enggan untuk mengikuti aktivitas di forum publik seperti Musrenbang, sehingga ini juga bisa menjadi kendala bagi keterlibatan perempuan di dalam forum publik.

3. Faktor rendahnya pendidikan perempuan yang berakibat tidak siapnya perempuan memasuki wilayah-wilayah publik yang kompetitif.

4. Tidak ada mekanisme yang diciptakan secara khusus agar perempuan yang masih lekat dengan peran domestiknya bisa secara maksimal untuk menjalankan aktivitas publiknya seperti waktu rapat yang mempertimbangkan kebutuhan perempuan.

\section{Kesimpulan}

Berdasarkan hasil analisis penelitian, maka dapat diperolehkesimpulan sebagai berikut:

Musrenbang Kota Mataram diselenggarakan berdasarkan pada Peraturan Walikota Mataram Nomor 8 Tahun 2016 Tentang Perubahan Atas Peraturan DaerahNomor 27 Tahun 2001 Tentang MusyawarahPembangunan Bermitra Masyarakat, pelaksanaan Musrenbang yang dilaksanakan di Kota Mataram Tahun 2017 telah berjalan sesuai dengan Peraturan Walikota Mataram.kehadiran perempuan di Kota Mataram belum mencapai kuota minimal $30 \%$ dari jumlah peserta,keterlibatan perempuan dalam komisi fisik dan prasarana $(0 \%)$, komisi umum $(11,8 \%)$, komisi ekonomi $(11,8 \%)$ dan komisi sosial budaya $(21,1 \%)$. Akses perempuan didalam Musrenbang Kota 
Mataram Tahun 2017 melalui sidang komisi paling banyak berada di komisi sosial budaya karena keahlian perempuan lebih dimanfaatkan dalam komisi sosial budaya dibandingkan dengan komisi yang lainnya. Minimnya tingkat keterlibatan perempuan dalam Musrenbang Kota Mataram tahun 2017 disebabkan oleh beberapa factor : Beban kerja domestik yang menimbulkan beban ganda bagi perempuan yang hendak beraktivitas public, Masyarakat yang telah menyakini bahwa perempuan identik dengan domestik maka menjadi wajar jika banyak perempuan yang enggan untuk mengikuti aktivitas di forum publik seperti Musrenbang,rendahnya pendidikan perempuan yang berakibat tidak siapnya perempuan memasuki wilayahwilayah publik yang kompetitif dan maskulin,aktivitas publik seperti waktu rapat yang mempertimbangkan kebutuhan perempuan.

\section{SARAN}

Untuk menyelesaikan permasalahan yang dihadapi oleh perempuan terkait dengan permasalahan aktivitas perempuan dengan mensosialisasikan arti pentingnya Musrenbang kepada berbagai pihak terutama perempuan sehingga perempuan di Kota Mataram mempunyai kepedulian dan pengetahuan tentang Musrenbang/MPBM

Dengan menempatkan perempuan dimasing-masing komisi maka perempuan mempunyai peluang dan kesempatan yang sama dengan laki-laki.

Terus-menerus memberikan dorongan dan kepercayaan penuh kepada perempuan untuk menduduki posisi-posisi strategis di Musrenbeng sehingga perempuan terlibat dalam proses pengambilan keputusan ditingkat kelurahan tersebut. Dan juga memberikan motivasi intensif kepada perempuan supaya perempuan memanfaatkan peluang dalam Musrenbang secara maksimal.

Untuk menyelesaikan permasalahan yang muncul akibat dari faktor-faktor penghambat perempuan dalam berpartisipasi di musrenbangkel, dapat diupayakan dengan:

1. Menciptakan mekanisme yang secara khusus agar perempuan yang masih terhambat dengan peran domestik dan kultur masyarakat bisa secara maksimal untuk mengikuti Musrenbang seperti waktu pelaksanaan Musrenbang di hari libur dan di siang hari.

2. Memberikan motivasi intensif kepada perempuan supaya perempuan memanfaatkan peluang dalam Musrenbang secara maksimal

DAFTAR PUSTAKA

Alexander Abe, 2001. Perencanaan Daerah Memperkuat Prakarsa Rakyat Dalam Otonomi Daerah. Lapera Pustaka Utama, Yogyakarta.

Anggarini, Yunita dan Puranto, Hendra, B., 2010. Anggaran Berbasis Kinerja PenyusunanAPBD Secara Komprehensif, UPP STIM YKPN, Yogyakarta.

Arifin Nasution. 2007. Perencanaan Pembangunan Partisipatif (Studi tentang Penyusunan Jangka Menengah Kota Medan Tahun 2006-2010). Medan: Universitas Sumatera Utara

Arikunto, Suharsimi. 2006. Metodelogi penelitian. Yogyakarta: Bina Aksara.

Baron \& Byrne. (2000). Social Psychology. (9th Edition). Massachusetts: APearson Education Company.

Bintoro Tjokroamidjojo, 1988, Pengantar Administrasi Pembangunan, LP3ES, Jakarta.

Bryant,Coralie\&LouiseG.White.1987.Manajem en PembangunanUntukNegara-negara Berkembang.Jakarta:LP3ES

Bogdan, R.C \& Biklen, S.K. 1982. Methods of Social Research. Boston: Allyn and Bacon, Inc.

Bogdan, Robert \& Steven J.Taylor. 1998. Introduction to Qualitative Research Methods, John Wiley \& Sons.

Bungin, B. 2007. Penelitian Kualitatif. Prenada Media Group: Jakarta. dkk. 2008. Penelitian Kualitatif; Komunikasi, Ekonomi, Kebijakan Publik, dan Ilmu Sosial Lainnya. Jakarta: Kencana.

Bradley, Tamsin. 2006. Challenging the NGOs: Women, Religion and Western.

Conyers, Diana. (1994). Perencanaan Sosial di Dunia Ketiga: Suatu Pengantar.Yogyakarta.Gadjah Mada University Press.

Dadang Juliantara. (2002). Pembaruan Desa: Bertumpu pada Apa yang 
Terbawa.Yogyakarta:Lapera Pustaka Utama

Depdiknas. (2001). Partisipasi Masyarakat. Jakarta: Depdiknas.

Fakih, M. (2006). Analisis Gender danTransformasi Sosial. Yogyakarta: Pustaka Pelajar.

Gatot Sulistoni, Hendriadi 2004. Anggaran Tak Sampai. Penerbit Solidaritas Masyarakat Transparansi NTB, Jl. Pariwisata N0.41 Mataram NTB 83121. Fax 0370-628251, email: somasi@indo.net.id

Hidayat syarif 2000. Refleksi Realitas Daerah

Dalam Tantangan Kedepan PT Pustaka Quatum :Jakarta.

Lugiarti E.2004. PartisipasiMasyarakat Dalam Proses Pembangunan. Khanata. Jakarta.

Mikkelsen. Britha, 2001. Metode Penelitian Partisipatoris dan Upaya-Upaya Pemberdayaan. Alih Bahasa Nalle, Matheos. Yayasan Obor Indonesia.Jakarta.

Moleong, Lexy J. 2007. Metodologi Penelitian Kualitatif. Bandung: Remaja Rosda Karya.

Moeljarto, T. 1987. Politik Pembangunan, Sebuah Analisis, Konsep, Arah danStrategi. Tiara Wacana. Yogyakarta.

Mubyarto. 2003. Pengantar Ekonomi Pertanian Edisi Ketiga. LP3ES. Jakarta

Munir. 2002. Perencanaan Pembangunan Daerah Dalam Perspektif Otonomi. NTB, Bappeda.

Nasution, S.2003.Metode Penelitian Naturalistik-Kualitatif. Bandung:Tarsito.

Oetomo, Budi Sutedjo Dharma. Perencanaan dan Pembangunan SistemInformasi. Yogyakarta: ANDI, 2002

Pierson, John. 2002. Tackling Social Exclusion. London and New York: Routledge.

Rogers, Everett M., dan Shoemaker, F. Floyd. (1981). Communication of Innovatin. Edisi Indonesia disarikan oleh Abdillah
Hanafi. Memasyarakatkan Ide Baru. Surabaya: Usaha Nasional.

Riyadi Dan Bratakusumah, 2005 : Peran Masyarakat dalam Pembangunan, Multigrafika,Jakarta.

Riant Nugroho, 2011. Gender dan Strategi Pengarus-Utamannya di Indonesia, Pustaka Pelajar, Yogyakarta.

Sastropoetro, Santoso. 1988. Partisipasi, Komunikasi, Persuasi, dan disiplindalam Pembangunan Nasional. Bandung : Alumni.

Sondang P. Siagian (2004). Manajemen

Sumber Daya Manusia.Penerbit

PT.Bumi Aksara, Jakarta.

Sumarto dan Hetifah (2003). Inovasi, Partisipasi dan Good Governance 20Prakarsa Inovatif dan Partisipatif di Indonesia. Jakarta: Yayasan OborIndonesia

Sugiyono. 2005. Memahami Penelitian Kualitatif. Bandung: ALFABETA.

Sumardjo dan Saharudin. 2003. Metodemetode Partisipatif dalamPengembangan Masyarakat. Bogor: IPB press.

Tjokroamidjojo, B. (1996), Perencanaan Pembangunan, Edisi ke -19, PT Gunung Agung, Jakarta.

Widodo, Tri. 2006. Perencanaan Pembangunan. Aplikasi Komputer (EraOtonomi Daerah). UUP STIM YKPN. Yogyakarta.

Zulkarimen Nasution, 2007. Komunikasi Pembangunan (Pengenalan Teori danPenerapannya). Yang Menerbitkan PT Raja Grafindo Persada : Jakarta

Undang-undang \& Peraturan Pemerintah : Undang-Undang Republik Indonesia No. 25 Tahun 2004, Tentang Sistem Perencanaan Pembangunan Nasional(Lembaga Negara Republik Indonesia Tahun 2004 Nomor 126);

Undang-Undang Nomor 22 Tahun 1999 Tentang Pemerintahan daerah Yang Kemudian Direvisi Menjadi UndangUndang Nomor 32 Tahun 2004 Tentang Pemerintahan Daerah Sebagaimana Telah Diubah Dengan Undang-Undang Nomor 23 Tahun 2014 tentang Pemerintahan daerah 
(Lembaran Negara Republic Indonesia Nomor 125 Tahun 2004);

UU Nomor 33 Tahun 2004 tentang Perimbangan Keuangan Antara Pemerintah Pusat dan Pemerintah Daerah

SE Bersama Menteri Negara Perencanaan Pembangunan Nasional/ Kepala Bappenas Dan Menteri Dalam Negeri Nomor 0259/M.PPN/I/2005050/166/SJ Tentang Petunjuk Teknis Penyelenggaraan Musrenbang Tahun 2005

Peraturan Daerah Kota Mataram Nomor 27

Tahun 2001 Tentang Musyawarah Pembangunan Bermitra Masyarakat;

Peraturan Walikota Mataram Nomor 35/KPTS/2004 Tentang Pedoman

Pelaksanaan MPBM

\section{Jurnal, Tesis \& Artikel Internet :}

Detha Riristuningsia, 2017, Partisipasi Masyarakat Dalam Perencanan Pembangunan Pedesaan (Studi Di Desa Lopok Kecamatan Lopok Kabupaten Sumbawa).

Diana Djuwita, 2009, Peran Perempuan Masyarakat Pesisir Dalam Meningkatkan Pendapat Keluarga Nelayan Di Desa Mertasinga.

Farida Hydro Foilyani, 2009, Pemberdayaan Perempuan Desa Dalam Pembangunan (Studi Kasus Perempuan Di Desa Samboja Kuala, Kecamatan Samboja, Kabupaten Kutai Kertanegara).

Harvard Institute For Internasional Development; Analisis Model Harvard Dan Women In Development (WID)

Hendriadi, 2016, Studi Fenomenologi Penerapan Prinsip Transparansi Dalam Perencanaan Dan Pengganggaran Di Kota Mataram. Unversitas Mataram

Hunia Djumati, 2010, Partisipasi Perempuan Dalam Pembangunan Desa di Kecamatan Kao Utara Kabupaten Halmahera Utara.

Listyaningsih, 2010, Partisipasi Perempuan Dalam Politik Dan Pembangunan di Banten
Murniati Ruslan, 2010, Pemberdayaan Perempuan Dalam Dimensi Pembangunan Berbasis Gender.

Oktaviani Adhi Suciptaningsih, 2010, Partisipasi Perempuan Dalam Lembaga Legislatif di Kabupaten Kendal.

Syaifullah, 2008, Analisis Perencanaan Pembangunan Tahunan Daerah di KotaMagelang (Studi Kasus Perencanaan Pembangunan Tahun 2007), Tesis,Program Pasca Sarjana Universitas Diponegoro, Magister IlmuAdministrasi, Semarang

Sahidu, A. 1998. "Partisipasi masyarakat tani pengguna lahan sawah dalampembangunan pertanian di daerah Lombok, NTB." Disertasi. Bogor:Program Pascasarjana IPB.

Soemarmo, 2005, Analisis Pelaksanaan Pendekatan Partisipatif Pada ProsesPerencanaan Pembangunan Di Kota Semarang (Studi KasusPelaksanaan Penjaringan Aspirasi Masyarakat Di KecamatanBanyumanik), Tesis, Magister Administrasi Publik, UniversitasDiponegoro, Semarang.

Triana Sofiani, 2009, Membuka Ruang Partisipasi Perempuan Dalam Pembangunan.

http://bapemas.jatimprov.go.id/index.php/prog $\mathrm{ram} /$ kegiatan-sosbud/287-sistemmanajemen-pembangunan-partisipatif$\underline{\mathrm{smpp}}$

http/:/dumadia.wordpress.com/2009/09/02/per encanaan-pembangunan- partisipatif/ Ardhana. Teknik Pengumpulan Data

Kualitatif. Tersedia: http://ardhana12.wordpress.com/2008 102/08/teknik-pengumpulan-datakualitatifl

Somerville, Peter. 1998. "Explanations of social exclusion: where does housing fit in?" Housing Study, Vol. 13, No. 6: 761-780.

http://mhs.blog.ui.ac.id/harry.surjadi/2 009/06/15/eksklusi-sosial-gender-danpembangunan/ 